\title{
凍結融解作用を受けるコンクリートの 劣化深度評価に関する基礎的研究
}

\author{
野口博章 $^{1} \cdot$ 満木泰郎 $^{2} \cdot$ 溝㴊利明 $^{3} \cdot$ 山田啓介 ${ }^{4}$ \\ 1正会員 東電設計(株) 第一土木本部水力部長( ( ⿳110-0015 東京都台東区東上野3丁目3-3) \\ E-mail:anoguchi@tepsco.co.jp \\ 2正会員 法政大学教授 工学部( ( 184-8584 東京都小金井市梶野町3丁目7-2) \\ 3正会員 法政大学教授 工学部( $\bar{T} 184-8584$ 東京都小金井市梶野町3丁目7-2) \\ 4正会員 東日本旅客鉄道(株) 研究開発センター(テ331-8513 さいたま市北区日進町 $2 丁$ 目 0$)$
}

\begin{abstract}
従来の促進凍結融解試験に替え, より実構造物の露出状況に近い, 一面からのみ促進凍結融解作用を受 けるコンクリートの劣化を実験的に検討し，劣化深度の評価方法について考察を加えた。対象としたコン クリートは，AE剂を用いないプレーンコンクリートである。実験の結果，同位の最低温度下における現 行の凍結融解試験結果を適用して, 深度方向の劣化予測を行った場合，表面部では耐凍害性を過小に評価 するものの，これに隣接する部材内部においては耐凍害性を過大に評価することが明らかとなった，その 原因の一つとして, 深度方向にひずみが変化することによって内部拘束的な自己平衡力が発生するための 影響が考えられることを示した。
\end{abstract}

Key Words : one side freeze and thaw test, lowest temperature, depth of deterioration

\section{1.はじめに}

コンクリートの凍結融解作用による劣化は，中性化あ るいは塩害などと並んで古くから知られる代表的なコン クリートの劣化形態の一つである. 凍結融解作用を受け たコンクリートの抵抗性の評価にあたっては, 従来より 促進試験が用いられ，なかでも供試体を水中に没し試験 に供する水中凍結水中融解試験法が一般的である.

この試験方法が我が国で実施されたのは, 戦後, 而梀 害性向上のためにAE剤の効果を実験的に検討した種々の 研究1)が契機と考えられる。これを境にコンクリートの 凍結融解抵抗性に関する研究は飛躍的に数を増し，コン クリートの耐凍害性向上，とりわけ材料の開発およひ配 合設計面に大きく貢献してきた.

しかし，既往の凍結融解抵抗性に関する研究成果は， 水中凍結水中融解試験法によって得られたものが主体で あり，筆者らはそれらの成果をそのままコンクリート構 造物に適用することについて未だ解決されていない問題 点が存在すると考えている. 現行の凍結融解試験結果を コンクリート構造物の耐久性評価に適用しようとした場 合, 促進試験であるため自然環境下とは最低温度および 凍結速度が大きく相違することならびに凍結融解が供試 体全面から作用し，一部の部材を除いてはそのような露
出環境は少ないことが問題点として挙げられるものと考 えている. このうち, 前者については筆者らの一人は現 位置の暴露試験との比較から試験時の最低温度と促進性 について考察を加えた22. しかし, 後者のそれについて は，研究事例が乏しい現状にある。凍結面を限定した試 験の研究例としては, 古くは鎌田らの研究3)があり, 比 較的新しい事例としては山下らの研究"がある.しかし, これらの成果を適用しようとした場合, 前者の研究では 対象としたコンクリートがALCといった特殊コンクリー トである点，また後者の場合には，気中凍結気中融解試 験であり, 現行までに多用され, 試験結果の蓄積が豊富 な水中凍結水中融解試験結果との直接比較は難しいもの と考えられる.

コンクリートは，社会資本を形成する主要な建設材 料であり, 新規に造られるコンクリート構造物の耐久性 評価はもとより, 既存のコンクリート構造物の耐久性を いかに評価するかも重要な課題である，その場合には， 深度方向の劣化予測が重要と考えられる. たとえば, 補 修を実施するに当たっては，除去を要する劣化した部分 の深さの予測, ならびに補修材との付着などを検討する ためには劣化した部分の力学特性の変化予測などが必要 となる.

本研究は, 現行の凍結融解試験装置を使用して, 凍 
結融解面を一面に限定した試験を実施し, 凍結融解面か らの距離と劣化の関係を求めた. その結果より，一面か ら凍結融解作用を受ける場合の抵抗性を, 従来の水中凍 結水中融解試験結果から予測する場合の問題点を明らか にした. また, 従来劣化指標として多用されている相対 動弾性係数の変化と力学性能の変化についても実験的に 検討した.

\section{2. 検討内容}

本研究は, 二つのシリーズで構成される. シリーズI は, 一面から凍結融解作用を受けたコンクリートの劣化 検討に係わるものであり, シリーズIは, 凍結融解作用 による力学性能変化検討に係わるものである. 試験に用 いたコンクリートは, 敢えてAE剂を用いないプレーン コンクリートとした。 その理由は, 試験結果に与える影 響の因子を明確にするためである. 寸なわち, 凍結融解 作用を受けるコンクリートの劣化も外力と耐力の大小関 係で定まると考えられるが，一面凍結融解作用という外

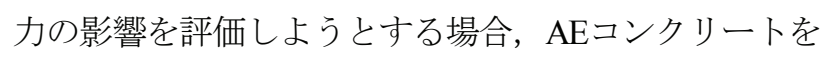
試験対象とした場合には耐力の影響が卓越すると考えら れるため, 外力の影響が顕在化しない恐れがあることを 考慮した。 また実務的には，未だAE剤が導入される以 前に建設されたコンクリート構造物, 例えば戦前に造ら れた水力発電設備関係のコンクリート構造物が多く存在 することを考えれば，試験結果はそのようなコンクリー 卜構造物の劣化評価を行う上で有用と考えられる.

\section{(1) シリーズI}

凍結融解作用を主として一面から受けるコンクリー 卜構造物の場合, その劣化は表面からの距離に応じて変 化すると考えられる. コンクリートの凍結融解抵抗性に 影響を及ぼす主たる要因は, 供試体が飽水状態にある場 合, 最低温度, 凍結速度および最低温度の保持時間が挙 げられる. 本研究では既往の研究成果 ${ }^{5}$ を参考に, この うち最低温度の影響が大きい点に着目し, 表面からの距 離による劣化の相違は表面から部材内部への最低温度の 変化による影響が支配的であると仮定した.

そこで，一面から凍結融解作用を受ける供試体以外 に, 最低温度を変化させた水中凍結水中融解試験を実施 し, 任意の最低温度およびサイクル数における劣化関数 を求めた.

つぎに, この劣化関数に一面凍結融解試験供試体内 の凍結面からの距離に応じた最低温度を代入することに よって, 凍結面からの距離に応じた劣化を予測し, 最低 温度を変化させた水中凍結水中融解試験から得られる予
測值と一面凍結融解試験から得られた試験值を比較する ことで, 従来の水中凍結水中融解試験結果と一面から凍 結融解作用を受ける場合の劣化の相違について分析を行 うこととした。

また，このシリーズでは，「長さ変化」を劣化指標 に取り上げたことを特徴としている. その有用性は, 古 くから認知されているの. すなわち, 劣化指標として一 般的に用いられている相対動弾性係数は, 試験中におけ るコンクリート強度の増進の影響を受けることが知られ ている7. 一方, 長さ変化は強度増進の影響を直接的に は受けないことから, 試験中に強度増進が懸念される場 合には，その有用性は高いと考えられる。一面から凍結 融解作用を受ける試験の場合, 深度方向に温度差が生じ ることから, これに応じて深度方向で強度増進にも差が 生じ, 相対動弾性係数の深度方向の変化が劣化の影響の みならず, 強度増進の影響をも受ける可能性が高いと考 えられる. そこで, 本研究においては, 従来の劣化指標 である相対動弾性係数に加え, 長さ変化も劣化指標とし て取り上げた。

\section{(2) シリーズII}

相対動弾性係数の変化に伴う力学性能の変化を検討寸 るために検討したシリーズである.

通常, 凍結融解試験によるコンクリートの劣化状態の 把握には動弾性係数などの非破壊試験による劣化指標を 用いる. 本シリーズでは, 凍結融解試験に供した試験体 を相対動弾性係数が80\%，70\%および60\%程度となったサ イクルで試験を中断し, 力学試験を実施し, 相対動弾性 係数の変化と力学性能の変化を実験的に明らかにした. 力学性能としては圧縮強度とヤング係数とした.

\section{3. 試験方法}

\section{(1) コンクリートの材料と配合}

\section{a) 使用材料}

セメントはT社製の普通ポルトランドセメントを用い た. シリーズエとシリーズாの実施時期は相違しており, セメントの製造ロットは相違している. 細骨材は鬼怒川 産の川砂・砕砂の混合砂であり, シリーズエでは, 密度 $2.59 \mathrm{~g} / \mathrm{cm}^{3}$, 吸水率 $2.25 \%$, 粗粒率 2.50 ののを, シリー ズIIでは, 密度 $2.60 \mathrm{~g} / \mathrm{cm}^{3}$, 吸水率 $2.07 \%$, 粗粒率2.73のも のを用いた. 粗骨材は岩瀬産の砕石であり, シリーズI では, 最大寸法 $25 \mathrm{~mm}$, 密度 $2.63 \mathrm{~g} / \mathrm{cm}^{3}$, 吸水率 $0.87 \%$ の のを, シリーズIでは, 最大寸法 $20 \mathrm{~mm}$, 密度 $2.64 \mathrm{~g} / \mathrm{cm}^{3}$, 吸水率0.90\%のものを用いた. また, 練混ぜ水には上水 道水を用いた。 
表-1 コンクリートの配合

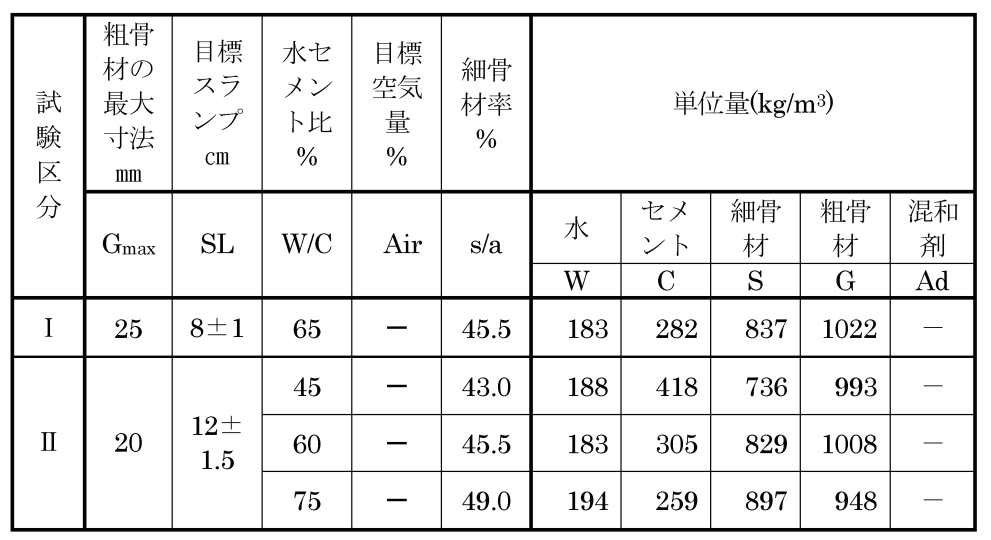

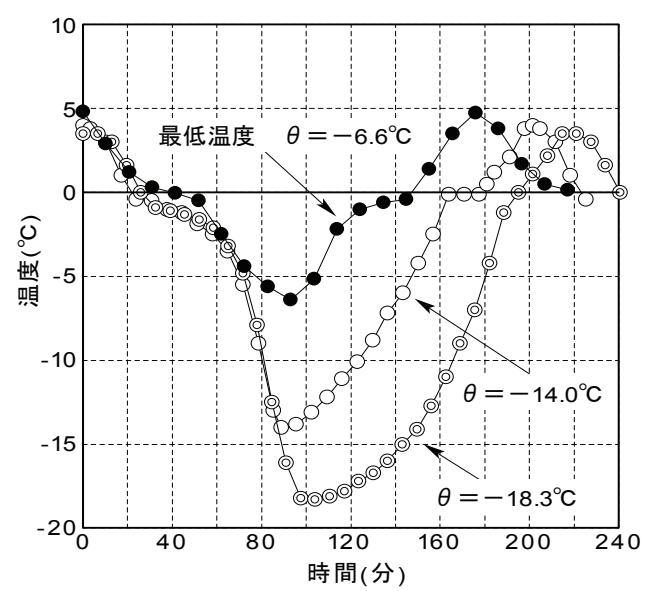

図-1＼cjkstart凍結融解 1 サイクルの温度履歴

\section{b) 配合}

シリーズIでは，水セメント比65\%，目標スランプ $8 \mathrm{~cm}$ のプレーンコンクリートとした. シリーズாでは，水セ メント比 $45,60,75 \%$, 目標スランプ $12 \mathrm{~cm}$ のプレーンコン クリートとした.

単位水量および細骨材率は試し練りによって定めた. コンクリートの配合を表-1に示す.

\section{（2）供試体および実験方法 \\ a) 供試体の作製}

シリーズ I では，角柱供試体および板状供試体（以 下，スラブ供試体と呼ぶ.）の 2 種類を用いた。角柱供 試体は，通常の水中凍結水中融解試験に供するものであ り，その寸法は $\mathrm{W} 10 \times \mathrm{H} 10 \times \mathrm{L} 40 \mathrm{~cm}$ である. また，スラブ 供試体は，一面凍結融解試験に供するものであり，その 寸法は $W 10 \times H 25 \times L 40 \mathrm{~cm}$ とした。 供試体数は，角柱供試 体の場合で 3 体，スラブ供試体の場合で 2 体づつとした。

スラブ供試体の打ち込み方向は, 高さ方向に材料分離 の影響が現れないように，角柱供試体と同様にコンクリ ートは供試体側面から打設した。

シリーズIでは， $\phi 10 \times \mathrm{H} 20 \mathrm{~cm}$ の柱供試体を用いた。 供試体数は, 凍結融解試験開始時のほか, 相対動弾性係 数が $80 \%, 70 \%$ おび60\%程度になった時点で力学試験に 供するために, 各水セメント比毎に, 12体づつを作製し た.

\section{b) ゲージプラグの供試体埋設}

シリーズリの供試体には長さ変化を測定するためのゲ ージプラグをコンクリート打設前より型枠に配すること で，コンクリート内に埋め込んだ. 角柱供試体では中央 部分に，スラブ供試体では凍結面から 1, 3, 5, 7.5, 10, $12.5,15 お よ ひ ゙ 20 \mathrm{~cm} の$ 位置に埋め込んだ.

\section{c) スラブ供試体の表面処理および養生}

コンクリート打ち込み後, 脱型までの 1 日間はコンク
リートを型わくごと湿布で覆い水分の蒸発を防ぐことと した.

シリーズ I では脱型後, 材齢 12 日までは $20 \pm 2{ }^{\circ} \mathrm{C} の$ 水中で，これ以降はスラブ供試体の表面処理の都合から 材齢 14 日までは $20 \pm 2^{\circ} \mathrm{C} の$ 恒温室内で基本的に封緘養 生とした。

スラブ供試体は，凍結融解試験中において凍結融解面 以外からの水分移動および蒸発散の防止を目的にコーテ イングを施した。 コーティング材には低温下においても 十分な柔軟性を持つT社製柔軟性エポキシ樹脂塗布剤を 用いた。

コーティング材塗布の際には，材齢 12 日で水中から 取り出した後, $20 \pm 2{ }^{\circ} \mathrm{C}$ 恒温室内で 12 時間放置し, そ の後コーティング材を凍結融解面以外の 5 面に塗布し材 齢 14 日まで静置した. この際，凍結融解面は，ビニー ルで覆い水分蒸発を防いだ。 また，角柱供試体は，スラ ブ供試体と同じ養生履歴となるように材齢 12 日以降, 恒温室に移し，コーティング材の塗布と同時に供試体を ビニールで包み込み，水分の蒸発を防いだ.

また，スラブ供試体は凍結面において側方コーティン グ材と凍結面コンクリートとの間には市販の家庭用防水 材パテを塗り込み，側面への水分吸水現象を防いだ。 こ の処置は，コーティング材と同様に供試体劣化測定時ご とにその劣化状況に併せて必要に応じ補修を行った。

シリーズ II では脱型後, 材齢 28 日まで $20 \pm 2{ }^{\circ} \mathrm{C}$ 水 中養生を行った.

\section{d) 促進凍結融解試験}

促進凍結融解試験は，JIS A 6204-2000 “コンクリー 卜用化学混和剂” 附属書 2 “コンクリートの凍結融解試 験方法”にならい, 冷液槽, 温液槽及び試験槽からなる 3 槽式の試験機を用いた. 試験時の管理用供試体の 1 サ イクル分の温度履歴を図-1 に示す. 最低温度を変えた 試験時のサイクルの制御に当たっては，凍結速度になる 


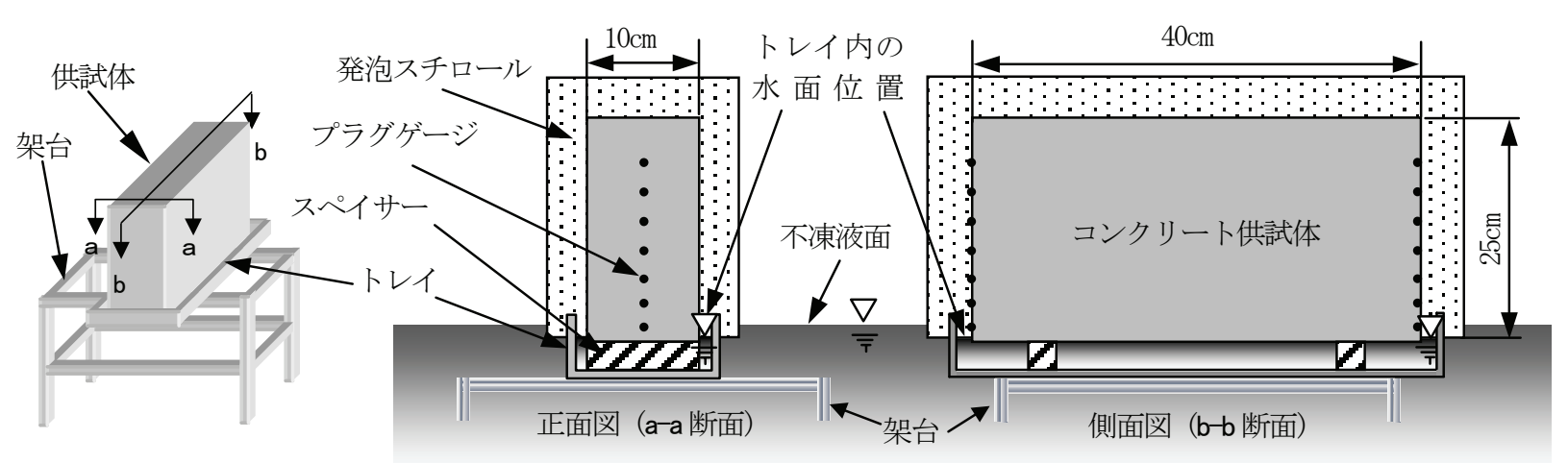

図-2 一面凍結融解試験供試体

ベく差が生じないようした. 凍結速度を同じにしようと すれば，最低温度が高くなるほど，1サイクルに要する

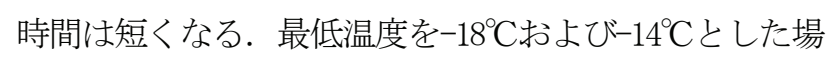
合の 1 サイクルに要する時間は, 最低温度を $-18^{\circ} \mathrm{C}$ と た場合の試験方法で規定される 3 時間以上 4 時間以内を 満足するが，最低温度を- $7^{\circ} \mathrm{C}$ とした場合には 3 時間をわ ずかに下回る結果となった。また，同図から最低温度を 変化させた試験の間で, 凍結速度および最低温度保持時 間に差はほとんど無いものと判断した. シリーズ I では, コンクリートの材齢が 14 日から，またシリーズ II では， コンクリートの材齢が 28 日から試験を開始した.

劣化の指標は, 超音波伝播速度から求めた相対動弾 性係数および長さ変化とした. 超音波伝播速度の測定は 供試体の長手方向とした.

測定は，所定サイクルごとに凍結融解試験機から供 試体を取り出し, $20 \pm 2{ }^{\circ} \mathrm{C}$ 水中に 2 時間放置し, 供試 体の測定時の温度を一定に保つように努め, その後 20 $\pm 2^{\circ} \mathrm{C}$ 恒温室において各種測定を行った.

\section{e) 1 面促進凍結融解試験}

1 面から給水並び涷結融解作用を与えるよう図-2 に 示すように，凍結融解試験槽内に架台を設け，この上に 水を張ったトレイ乗せ，その中にスペーサを介して供試 体をセットした.

トレイは，厚さ $0.2 \mathrm{~mm}$ の亜鉛鋼板を内空寸法が W12 $\times$ H5 $\times$ L $42 \mathrm{~cm}$ となるように作製し，この中に水深 $3 \mathrm{~cm}$ と なるように水を張った. トレイは架台を介して凍結融解 試験槽にセットし，その高さはトレイ内側の水面の高さ と不凍液面とほぼ等しくなるように架台の高さを調整し た．スペーサはその材質がコンクリート凍結面一の水分 および熱伝導の影響が少なくなることを目的として高さ 2. $5 \mathrm{~cm}$ の木材を用いた. したがって, 供試体は表面から $5 \mathrm{~mm}$ の部分までが水と接触する. また, 供試体周辺に は厚さ $5 \mathrm{~cm}$ の発泡スチロールを配置し, 供試体の側方 への熱移動を防ぐよう努めた。
供試体内部の温度は, 劣化測定用供試体とは別に, 各深さごとに温度測定用熱電対を予め埋め込んだ温度測 定用供試体を作製し，劣化測定用供試体と同じ条件下で 測定した. また, 凍結融解面にも熱電対を接着し, コン クリート表面での温度も測定した.

槽内の温度制御は, 通常の促進凍結融解試験と同様 に角柱の温度管理用供試体によって行い，その中心の最 低温度は-18 $\mathrm{C}$ とした。

劣化の指標は, 超音波伝播速度から求めた相対動弾性 係数および長さ変化とした. 超音波伝播速度の測定は供 試体の長手方向とした.

\section{4. 凍結融解試験結果}

\section{(1)最低温度が劣化に及ぼす影響}

\section{a) 相対動弾性係数変化および長さ変化}

最低温度を $-18^{\circ} \mathrm{C},-14^{\circ} \mathrm{C}$ おび $-7^{\circ} \mathrm{C}$ とた場合の相対 動弾性係数の変化を図-3に, 長さ変化を図-4に示寸.

これによれば，いずれの最低温度下においても凍結融 解サイクル数の増加に伴い相対動弾性係数は低下し, 長 さ変化は増加することが認められる．これらの劣化の程 度は, 最低温度が低いほど大きくなる状況が明瞭に示さ れている.ここで, 各測定結果を結んだ曲線は, 次節で 示寸回帰曲線である.

\section{b) 任意の最低温度下の劣化}

本節では, 後述のスラブ供試体の深度毎に相違する 最低温度に応じた劣化を同温度下における角柱供試体の 劣化から予測するために, 任意の最低温度下における劣 化関数をa)に示した実験結果を基に求める.

まず, 相対動弾性係数を式(1)で, 長さ変化を式(2)で 回帰した.

$$
E d=100 \exp \left(-\alpha \cdot c_{c l} e^{\beta}\right)
$$




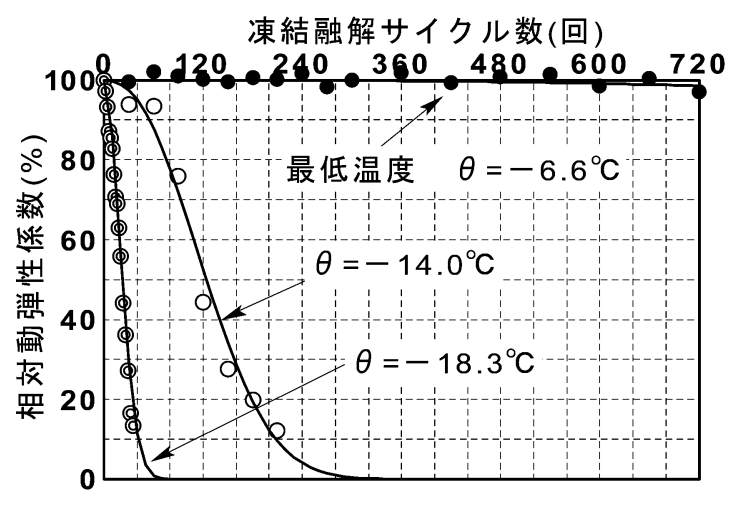

図-3 相対動弾性係数の変化

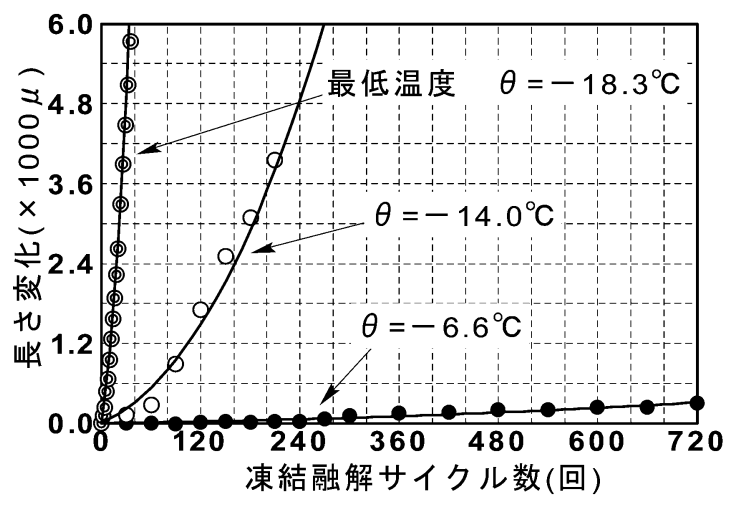

図-4 長さ変化の変化

表-2 回帰係数

\begin{tabular}{|c|c|c|c|c|}
\hline \multirow{2}{*}{$\begin{array}{c}\text { 最低温度 } \\
\left({ }^{\circ} \mathrm{C}\right)\end{array}$} & \multicolumn{2}{|c|}{ 相対動弾性係数 } & \multicolumn{2}{|c|}{ 長さ変化 } \\
\cline { 2 - 5 } & $\alpha$ & $\beta$ & $\alpha$ & $\beta$ \\
\hline-6.6 & $5.06 \times 10^{-11}$ & 2.944 & 0.838 & 0.293 \\
\hline-14.0 & $6.52 \times 10^{-6}$ & 2.413 & 2.623 & 0.216 \\
\hline-18.3 & $2.44 \times 10^{-3}$ & 1.862 & 4.602 & 0.178 \\
\hline
\end{tabular}

$$
(1+L)=\exp \left(\alpha \cdot \operatorname{cycle}^{\beta}\right)
$$

ここで, $E d$ : 相対動弾性係数 $(\%), L$ : 長さ変化 $(\mu)$, cycle: 凍結融解サイクル数 (回), $\alpha, \beta$ :回帰係数である.

回帰係数を表-2 に示す.

つぎに, 上記回帰関数の回帰定数 $\alpha, \beta$ と最低温度 $\theta$ の関係を示せば図-5 および図-6 に示すとおりであり,

これを図中に示した関数で回帰した. この回帰係数を用 いて最低温度および凍結融解サイクル数で回帰した結果 を図-7および図-8に示す.

以上の結果を基に，先に示した試験時の最低温度を 入力值とし, 凍結融解サイクル数の変化に伴う相対動弾 性係数および長さ変化を求めた結果は, 先の図-3 およ び図-4 に示した曲線のとおりであり, 回帰曲線は試験

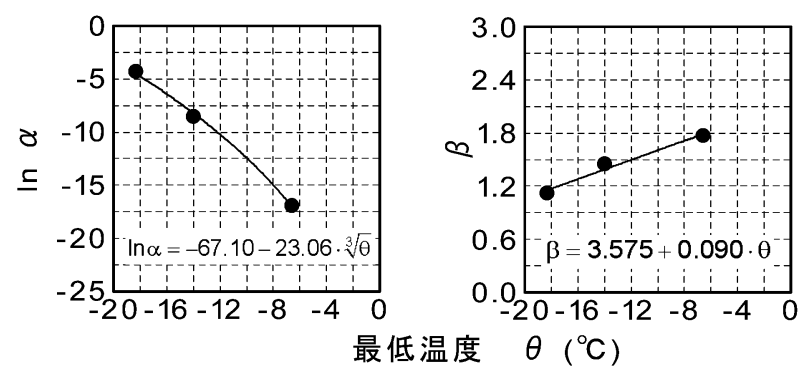

図-5 相対動弾性係数の回帰係数

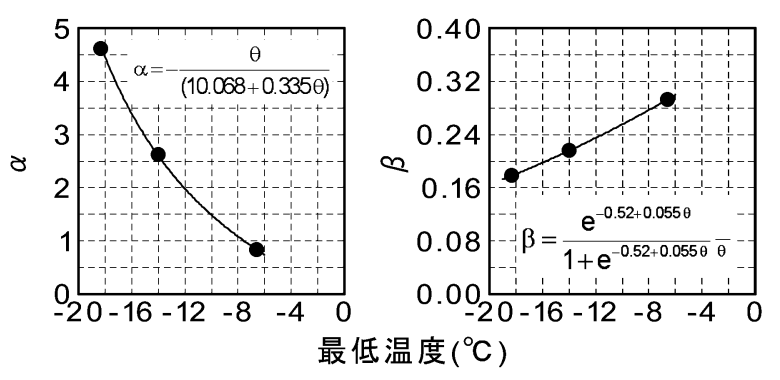

図-6 長さ変化の回帰係数

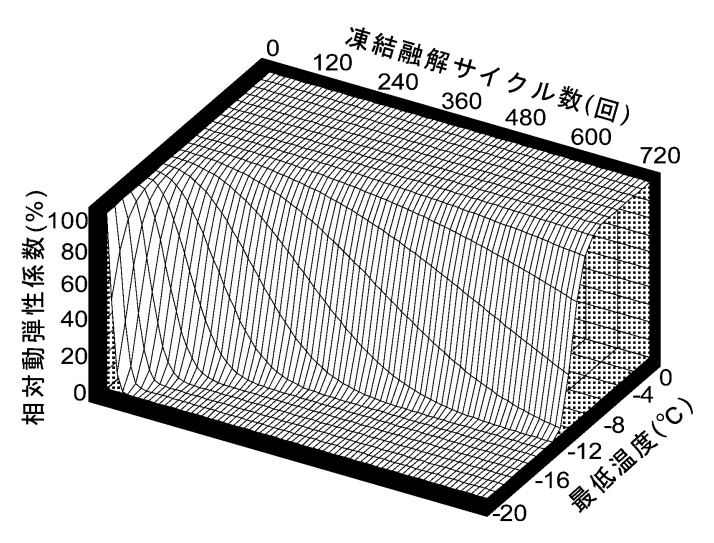

図-7 相対動弾性係数の回帰

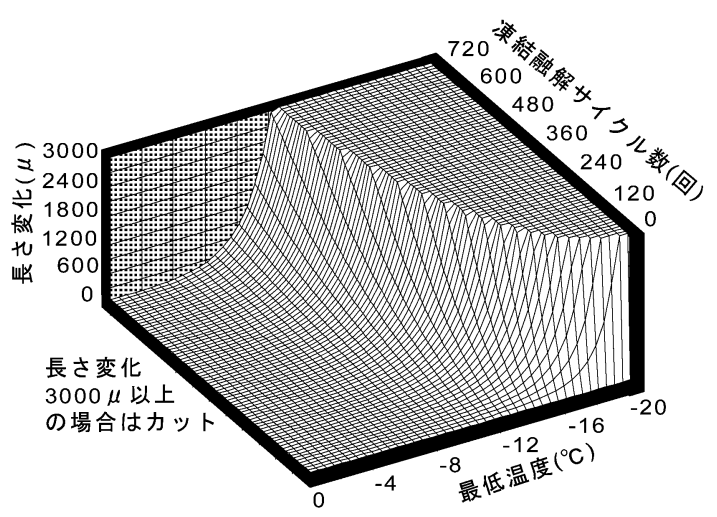

図-8 長さ変化の回帰 


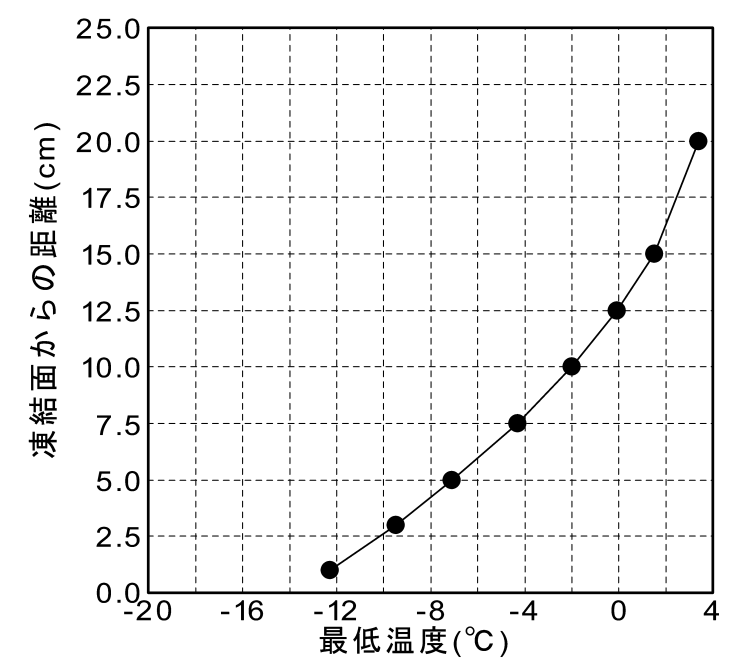

図-9 スラブ供試体内の最低温度分布

值を非常に良く捉えており，回帰精度が高いことが認め られる。

\section{(2) 一面凍結融解作用による劣化}

\section{a) スラブ内の最低温度}

スラブ内における最低温度の分布を図-9 に示す。こ こで最低温度は，300 サイクルまでの各位置での各サイ クル毎の最低温度平均值である。したがって，同時刻に おける温度分布を示しているとは限らない。

これによれば，槽内に設置した管理供試体の最低温

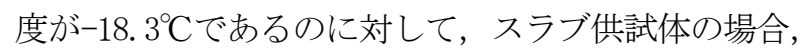
凍結面からの距離 $1 \mathrm{~cm}$ の位置における最低温度は $-12.3^{\circ} \mathrm{C}$ であった。このようにスラブ供試体の温度が角 柱供試体のそれと比較して高温である理由は，各面から 冷却されることがないこと，スラブ凍結面と不凍液面に はトレイを介して厚さ約 $3 \mathrm{~cm}$ 程度の水を介している影 響と考えられる。 また，スラブ供試体では凍結融解面か らの距離が $12.5 \mathrm{~cm}$ 以上ではその最低温度は $0^{\circ} \mathrm{CW上で}$ あり, 凍害を受けない可能性が高いものと想像される.

\section{b) スラブ内の相対動弾性係数}

スラブ内における相対動弾性係数の変化を凍結融解 面からの距離別に図-10に示す.

試験は，300 サイクルまで継続しているが，距離 $1 \mathrm{~cm}$ の箇所では 270 サイクル以降ゲージプラグが緩むととも に断面欠損が生じたため測定不能となっている.

図-10によれば，凍結融解面に近いほど相対動弾性係 数の低下が大きいことが認められる. しかし，その傾向 は表面からの距離が $5 \mathrm{~cm}$ までであり，7.5cm 以上の部分 においては相対動弾性係数の低下はほとんど認められず, 凍結融解サイクル数の増加に伴い相対動弾性係数は増加 する傾向にある. これは，凍結融解試験期間中，とりわ け 30 サイクル毎の測定時に $20^{\circ} \mathrm{C}$ 環境下に置かれるた

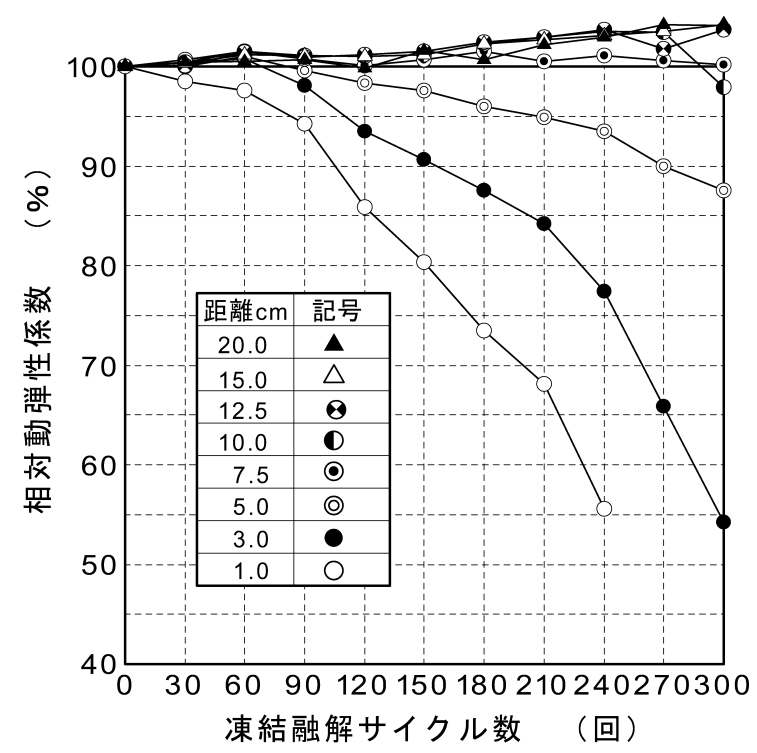

図-10 スラブ供試体内の相対動弾性係数

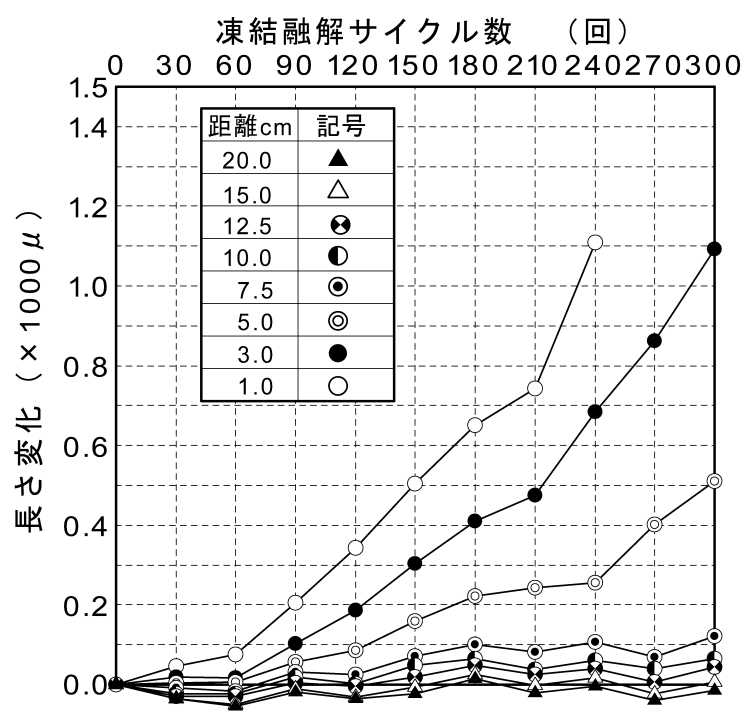

図-11 スラブ供試体内の長さ変化

めに，その間の強度増加の影響を受けたためと考えられ る. 特に, 図-9 に示した温度分布からも判るように距 離 $12.5 \mathrm{~cm}$ 以上の部分では最低温度が水点下にならない ために, 凍害による劣化は現れないものと考えられる.

また，一面から凍結融解作用を受ける試験では深度 方向に劣化の程度に相違が生じることから, 劣化測定指 標として超音波伝播速度から求める相対動弾性係数を用 いた場合では，伝播経路の影響で劣化部の相対動弾性係 数を過大に見積もることも考えられる. すなわち, 深度 方向に劣化の程度が連続的に変化する場合, 超音波の伝 播経路が本来測定しようとする位置に近接する相対的に 劣化の程度が小さい部分をより選択的に通過する可能性 


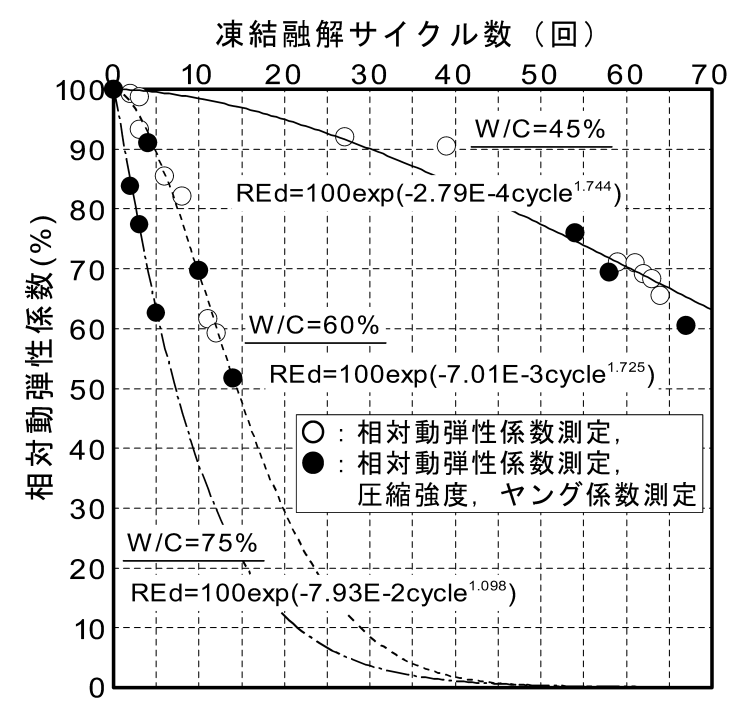

図-12 円柱供試体の相対動弾性係数

も否定できない.

\section{c) スラブ内の長さ変化}

劣化指標を凍結融解試験中において強度増進の影響 を受けにくいと考えられる長さ変化とした場合の測定結 果を図-11 に示す。これによれば，凍結面からの距離が 短いほど長さ変化が大きく, 凍結面に近いほど劣化し易 い傾向が示されており，その程度は劣化指標を超音波法 による相対動弾性係数を用いた場合よりも明瞭に現れて いる. しかし, 相対動弾性係数の場合と同様距離 $7.5 \mathrm{~cm}$ 以上の部分では長さ変化が小さく, 劣化が小さいことが 認められる.

\section{(3) 凍結融解作用による力学性能変化 \\ a) 相対動弾性係数の変化}

最低温度を $-18^{\circ} \mathrm{C} と し$, 水セメント比を $45 \%, 60 \%$ お び 75\%とした場合の相対動弾性係数の変化を図-12 に示 す.ここで, 相対動弾性係数を求めた供試体数はサイク ル数で異なる.すなわち, 本シリーズでは相対動弾性係 数が $80 \%, 70 \%$ および $60 \%$ 程度となった時点で供試体を各 3 体づつ力学試験に供することから, 凍結融解試験開始時 においては各水セメント比とも 9 体あるが，相対動弾性 係数が 60\%程度となった時点では 3 体である.

これによれば, 水セメント比が高いものほど劣化しや すいことが明瞭に確認される.

\section{b) 力学性能比の変化}

凍結融解試験開始直前の圧縮強度およびヤング係数に 対して，相対動弾性係数が 80, 70 および 60\%程度となっ た時点の比をとり，それぞれ圧縮強度比およびヤング係 数比と定義し, これらを併せ力学性能比と呼ぶこととす る. 相対動弾性係数と圧縮強度比の関係を図-13に，ヤ

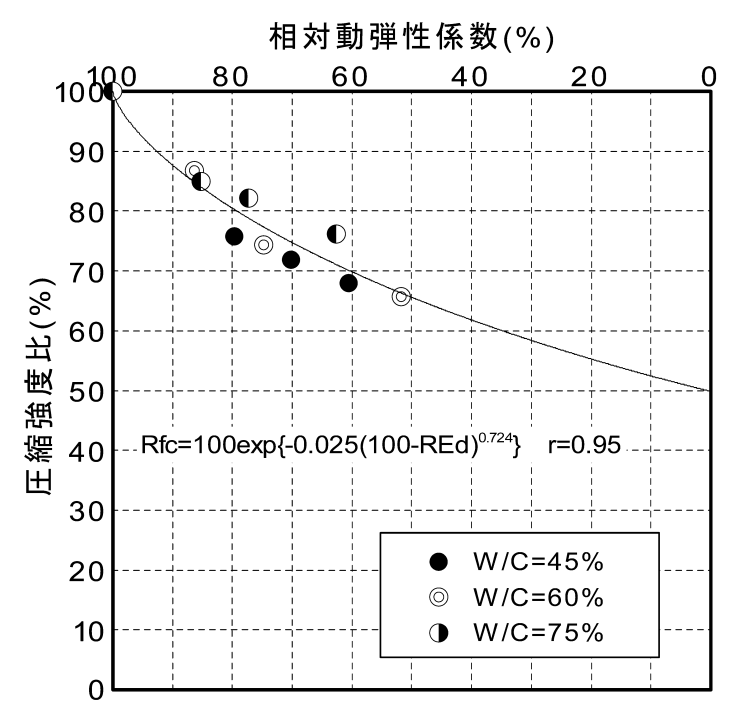

図-13 相対動弾性係数と圧縮強度比の関係

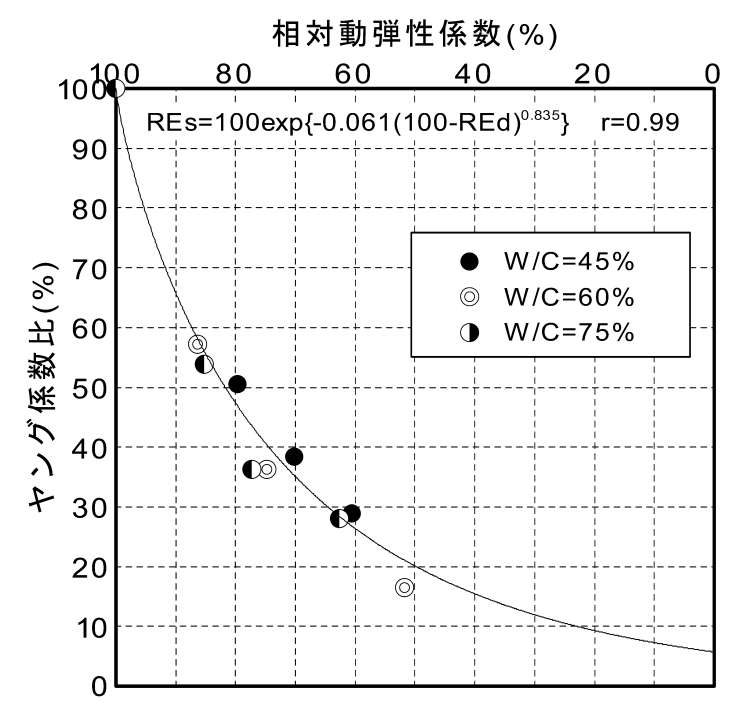

図-14 相対動弾性係数とヤング係数比の関係

ング係数比との関係を図-14 に示す。これによれば，相 対動弾性係数の低下とともに力学性能比は低下するが, その程度は力学性能で相違し, 圧縮強度の低下は動弾性 係数の低下より小さく, ヤング係数の低下は動弾性係数 の低下よりも大きく, ヤング係数の低下の方が圧縮強度 の低下と比較して大きいことが認められる，例えば，相 対動弾性係数が 60\%程度となった時点における力学性能 比を比較すれば，圧縮強度比が 70\%程度であるのに対し て, ヤング係数比は 30\%程度であり, ヤング係数の低下 が圧縮強度の低下よりも大きいことが認められる。また， 相対動弾性係数の低下と圧縮強度比あるいはヤング係数 比の低下は水セメント比によらず，ほぼ一つの曲線で表 すことが可能であることが認められる. 


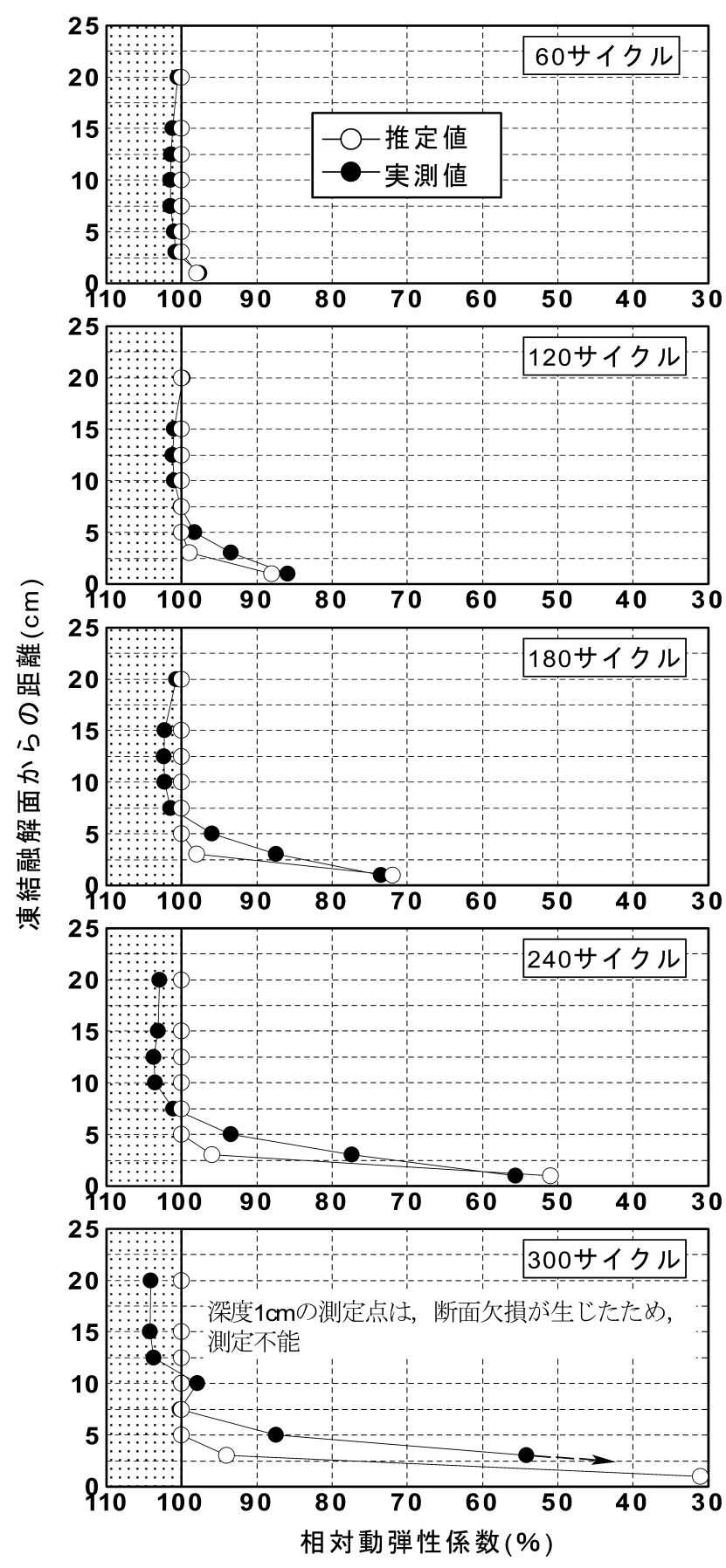

図-15 相対動弾性係数の実測值と推定值

5. 一面から凍結融解作用を受けるコンクリート の劣化評価

\section{(1)スラブ内の最低温度に応じた劣化の推定}

スラブ内の最低温度に応じた劣化の予測を角柱供試 体の試験結果から推定寸る. 寸なわち, 図-9 に示した スラブ内の各点の最低温度をもとに，4 章で示した任意 の最低温度下での相対動弾性係数および長さ変化を求め る手法を用い, それらを推定した。

相対動弾性係数の推定結果を図-15に, 長さ変化の推

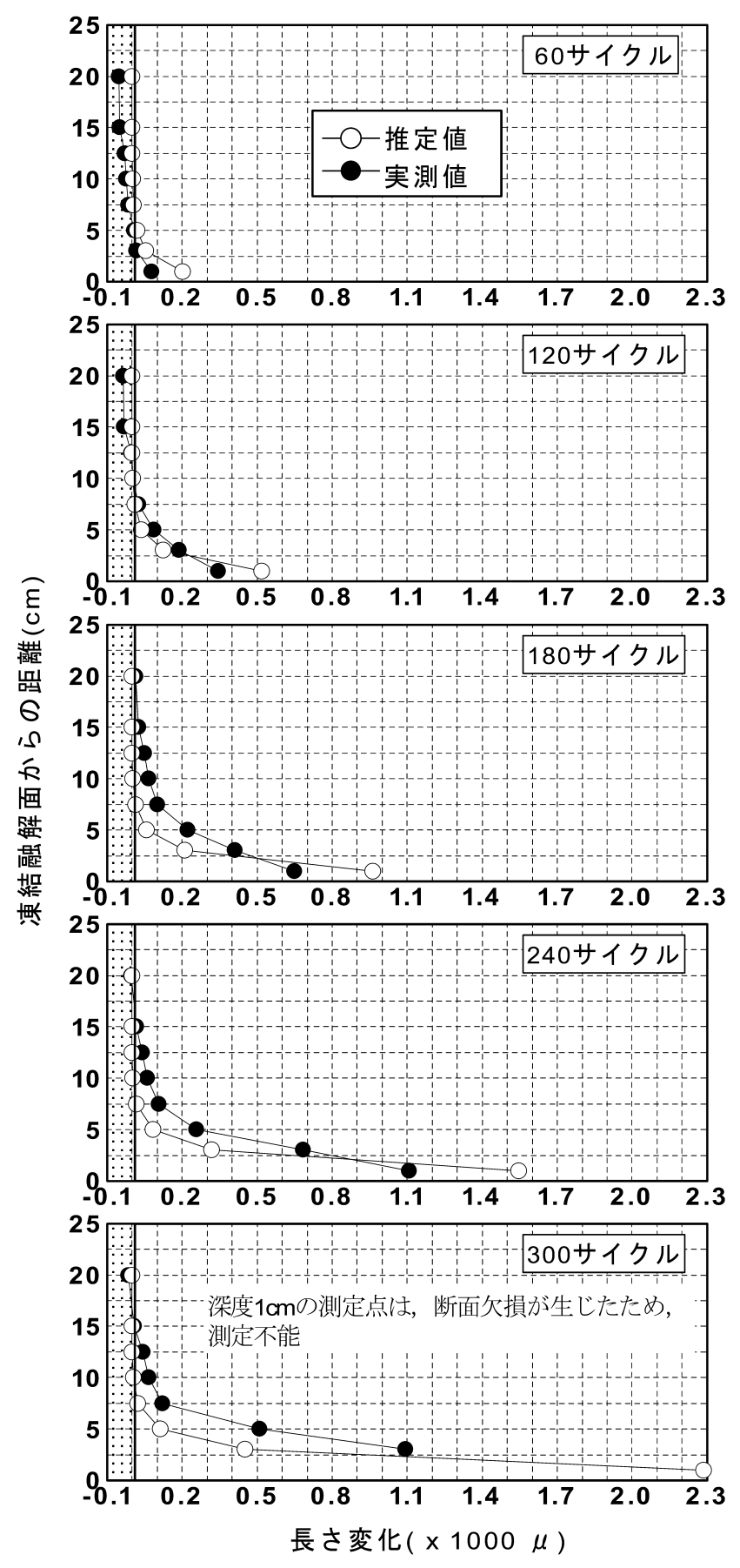

図-16 長さ変化の実測值と推定值

定結果を図-16 に，それぞれ実測の結果とともに 60 サ イクルごとに示す.

\section{a) 相対動弾性係数}

相対動弾性係数の推定值が 100\%を下回る位置は凍結 融解面からの距離が $5 \mathrm{~cm}$ 程度までの領域である. 距離 $5 \mathrm{~cm}$ における最低温度の実測值は，図-9 によれば-7 $7^{\circ} \mathrm{C}$ 程 度であり，図-3 に示した最低温度を変化させた凍結融 解試験結果からは，この程度の最低温度における相対動 弾性係数の低下がほとんど見られなかったことが反映さ れている. 
一方, 実測值は $5 \mathrm{~cm}$ 程度ではすでに相対動弾性係数 が 100\%を下回っていることが認められ，推定值と実測 值の差はサイクル数が増加するほど大きくなることが認 められる，例えば， $5 \mathrm{~cm}$ の位置で観た場合，120 サイク ルにおける推定值は $100 \%$ であるのに対して，実測值は 98\%であるが，300 サイクルにおける推定值と実測值は 100\%と 88\%であり, サイクル数の増加に伴い, 推定值と 実測值の差が大きくなり, 推定值は相対動弾性係数を過 大に，言い換えれば劣化を過小に評価する傾向が認めら れる. その傾向は凍結面との距離がさらに近くなる $3 \mathrm{~cm}$ ではより一層明瞭となる. 同じように 120 サイクルおよ び 300 サイクルにおける推定值と実測值を比較すれば, 99\%と 94\%および 94\%と 54\%であり, サイクル数の増加と ともに推定值と実測值の差が大きくなることが認められ る.

しかし，距離 $1 \mathrm{~cm}$ では推定值と実測值は同程度，も しくは推定值の方が相対動弾性係数を過小に評価する傾 向にある. 距離 $1 \mathrm{~cm}$ の位置では 270 サイクル測定時に当 該䇢所に断面欠損を生じたため, 実測值が久測となって いることから，ここでは 120 および 240 サイクルにおけ る推定值と実測值を比較する. 120 サイクルにおける推 定值と実測值は 88\%と 86\%であり，同程度であるが，240 サイクルでは $51 \%$ と $56 \%$ と, 推定值の方が相対動弾性係 数を過小に，換言すれば劣化を過大に評価することが認 められる.

\section{b) 長さ変化}

長さ変化の推定值と実測值の関係も相対動弾性係数 と同じ傾向にあり, 凍結融解面からの距離が $3 \mathrm{~cm}$ より も内部の領域では, 推定值の長さ変化は実測值のそれと 比較して小さく評価し, 実測に対して劣化を過小に評価 していることが認められれる.

すなおち, 距離 $3 \mathrm{~cm}$ における 120 サイクル時の推定値 が $123 \mu$ であったのに対して実測值は $186 \mu$ であり, 300 サイクルではそれぞれ $452 \mu$ と $1093 \mu$ であり, 推定值の 方が長さ変化が小さく, 劣化を過小に評価していること が認められる. 一方, 距離 $1 \mathrm{~cm}$ においては, 120 サイク ル時および 240 サイクル時で推定值と実測值を比較すれ ば，それぞれ $517 \mu$ と $344 \mu$ および $1545 \mu$ と $1109 \mu$ と， 相対動弾性係数の場合と同様に推定值の方が劣化を過大 に評価していることが認められる。 また, 実測值で注目 すべき点は, 深さ $7.5 \mathrm{~cm}$ よりも梁部の位置である.この 位置付近の最低温度は $-4{ }^{\circ} \mathrm{C}$ 程度であり, 同温度位の角柱 供試体の試験結果からの推定值からは, ほとんど劣化し ていないと推定されるが，実測値はひずみが残留してい ることが認められる。

以上の結果をまとめれば，一面凍結融解作用を受け る場合の劣化予測を同一最低温度下の水中凍結水中融解
試験を基に推定した場合, 表面に近い位置では劣化を過 大に評価し, 内部では劣化を過小に評価してしまうこと が確認された。

\section{(2) 一面凍結融解作用を受けるコンクリートの劣化}

推定值に対して実測值が，表面では劣化し難く，内 部が劣化し易くなる原因のひとつとして, 本来劣化が大 きくなる表面部分を相対的に劣化が小さい内部が拘束す るための影響と考えられる.

すなわち, スラブ内の最低温度分布を基に水中凍結水 中融解から求めた長さ変化は, 単一の最低温度下におけ る残留ひずみである. これに対して，一面凍結融解試験 から求められた長さ変化は, スラブ内部での当該位置で の最低温度による劣化の影響のほか, 最低温度の高さ方 向への変化に伴う劣化の相違の影響, 寸なわち内部拘束 の影響が生じているものと考えられる.

このような考察を確認するために, 高さ方向に拘束 されない自由な任意のひずみ分布に対して，これが連続 してスラブ内に分布したと仮定した場合のスラブ内に発 生するひずみを求める.

\section{a) 凍結時の組織のモデル化}

長さ変化で求められたひずみは, 融解時の残留ひずみ であり, 非弾性ひずみである. その值の大小は組織に与 えられた損傷の程度を表し, 凍結時に発生する圧力, 寸 なわち間隙水が水から水へと相変化する際の体積膨張力 あるいは体積澎張に伴って発生すると考えられている未 凍結水の移動圧などの圧力に深く関連していると考えら れる. 本研究では, 凍結時にコンクリート内に発生する ひずみを計測していないために，これを正確には求めら れない，そこで，凍害を受けたコンクリート組織を図一 17 のようにモデル化し, 凍結時においては, 水隙部は 氷で満たされ, 非劣化部分と合わせて弾性的な挙動を示 すものと仮定する.

すなわち, 非劣化状態の硬化セメントペースト組織は, ある最低温度下では凍結しない水隙を含む固相, ある最 低温度下で涷結する液相，ならびに気相の三相から成っ ているものと仮定する（図中，（A）の状態）。凍害劣 化した組織では凍結融解作用によって組織が弛緩された 相（以下, 脆弱相と呼ぶ.）が形成されるものと仮定す る (図中, (B) の状態) 。この状態を, さらに凍結時 と融解時には同図の (C)および(D)のように，二相モデル に置き換えることとする. 寸なわち, 非劣化状態の組織 から成る基相と水隙の周辺に形成された脆弱相の二相か ら成るモデルに置き換え, 凍結時には脆弱相が氷相へと 変化し, 融解時には脆弱相が液相へと変化するものと考 える. 凍結融解作用に伴う劣化は, 組織中に占める脆弱 相の割合が次第に増加するためと仮定する. また, 凍結 
非劣化状態の組織

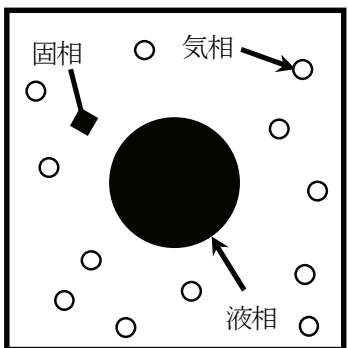

(A) 固相十液相十気相
凍害劣化した組織

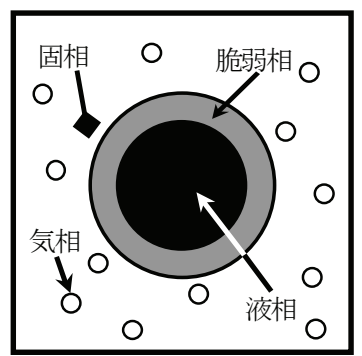

(B) 固相十液相十気相十脆弱相
凍結時の 2 相モデル

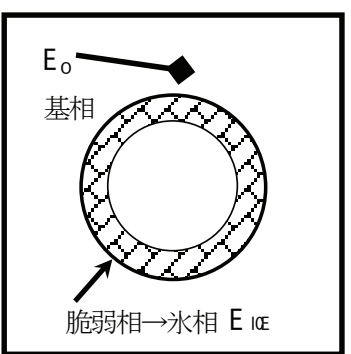

（C）基相十水相
融解時の 2 相モデル

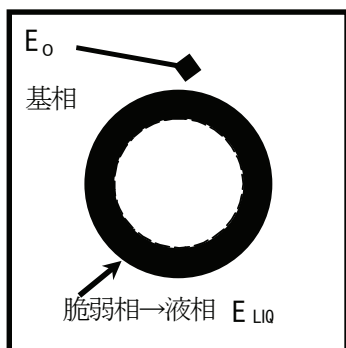

（D）基相十液相

図-17凍結時と融解時の組織のモデル化

時には，脆弱相が基相中の水隙とともに凍結するものと して，基相とともに弾性的に挙動するものと仮定する. すなわち，融解時には脆弱相は非弾性状態にあるが，凍 結時には組織内部の水が凍結することによって，弾性的 に挙動するものと仮定する.

\section{b) 内部拘束力によるひずみの算出方法}

凍結時には，弾性的に挙動すると仮定し，供試体高さ 方向には，劣化の相違に伴う内部拘束力が作用するもの とする. したがって, 融解時に計測される長さ変化は, 単一最低温度に基づく劣化による残留ひずみと内部拘束 力の発生に起因する残留ひずみの和として表されるもの と考える. 内部拘束力の発生に起因する残留ひずみは, 発生した弾性ひずみの一部が残ると仮定し, その比率を $\varphi$ とする.

$$
\varepsilon=\varepsilon_{t}^{p}+\varepsilon_{i}^{p}=\varepsilon_{t}^{p}+\varphi \cdot \varepsilon_{i}^{e}
$$

ここで， $\varepsilon$ : 長さ変化, $\varepsilon_{t}^{p}$ : 凍結融解面からの高さ に応じた最低温度に基づく残留ひずみ， $\varepsilon_{i}^{p}$ : 内部拘束 力の発生に起因する残留ひずみ, $\varphi$ : 残留率, $\varepsilon_{i}^{e}$ : 内 部拘束力の発生に起因する弾性ひずみである.

内部拘束力の発生に起因する弾性ひずみの算定には, 温度応力を検討する際に用いられるコンペンセイション ライン法によるものとする.

$$
\begin{gathered}
\varepsilon_{i(y)}^{e}=\left(\varepsilon_{(y)}^{F}-\varepsilon_{(y)}^{c p}\right) \\
\varepsilon_{(y)}^{c p}=\frac{\sigma_{(y)}}{E_{(y)}}=\frac{1}{E_{(y)}}\left(\frac{N_{(y)}}{A}+\frac{M_{(y)}}{I} y\right) \\
=\frac{1}{E_{(y)}}\left(\frac{b \int_{0}^{H} E_{(y)} \varepsilon_{(y)}^{F} d y}{b H}+\frac{b \int_{0}^{H} E_{(y)} \varepsilon_{(y)}^{F} d y \bullet e}{\frac{b H^{3}}{12}} y\right)
\end{gathered}
$$

$$
e=\frac{M}{N}-\frac{H}{2}=\frac{\int_{0}^{H} E_{(y)} \varepsilon_{(y)}^{F} y d y}{\int_{0}^{H} E_{(y)} \varepsilon_{(y)}^{F} d y}-\frac{H}{2}
$$

ここで, $\varepsilon_{i(y)}^{e}$ : スラブ内に発生するひずみ, $\varepsilon_{(y)}^{F}$ : 最低温度に基づくひずみ, $\varepsilon_{(y)}^{c p}$ : コンペセイションひず み, $y$ : 凍結融解面力らの距離, $\sigma_{(y)}$ : 応力, $E_{(y)}$ : ヤング係数, $N_{(y)}$ : 軸力, $A$; 断面積, $M_{(y)}$ : モ一メ ント, $I$ : 断面二次モーメント, $b$ : 幅, $H$ : 高さ, $e$ : 偏心距離である.

\section{c) 凍結時におけるコンクリートのヤング係数}

ここでは，凍結時におけるヤング係数の算出方法に ついて述べる.

凍結融解作用に伴うヤング係数の変化は先に図-14 に 示したとおりであり，この值は図-17(D)に示した融解時 の值を示しているものと考えられる. 二相混合体のヤン グ係数を求める方法としては, Voigt あるいは Reuss の 方法 ${ }^{8}$ があるが，本研究では，評価されるヤング係数が これらの中間に位置する大嶺・落合 ${ }^{9)}$ の研究成果を参照 することとした. 大嶺の方法を用い，図-17(D) の融解 時における二種混合体のヤング係数は，式(6)に示すよ うに求めることができる.

$$
E_{S}^{T}=\frac{(\alpha-1) p+1}{\frac{\alpha \cdot p}{E_{L I Q}}+\frac{1-p}{E_{0}}}, \quad \alpha=\sqrt{\frac{E_{L I Q}}{E_{0}}}
$$

ここで， $E_{S}^{T}:$ 二相混合体のヤング係数 (融解時にお けるヤング係数), $p$ : 介在物（脆弱相）の比, $E_{L I Q}$ : 脆弱相の融解時のヤング係数, $E_{0}$ : 基相のヤング係数 である。

これを変形して脆弱相の比 $p$ を求めれば式(7)のとお りである. 


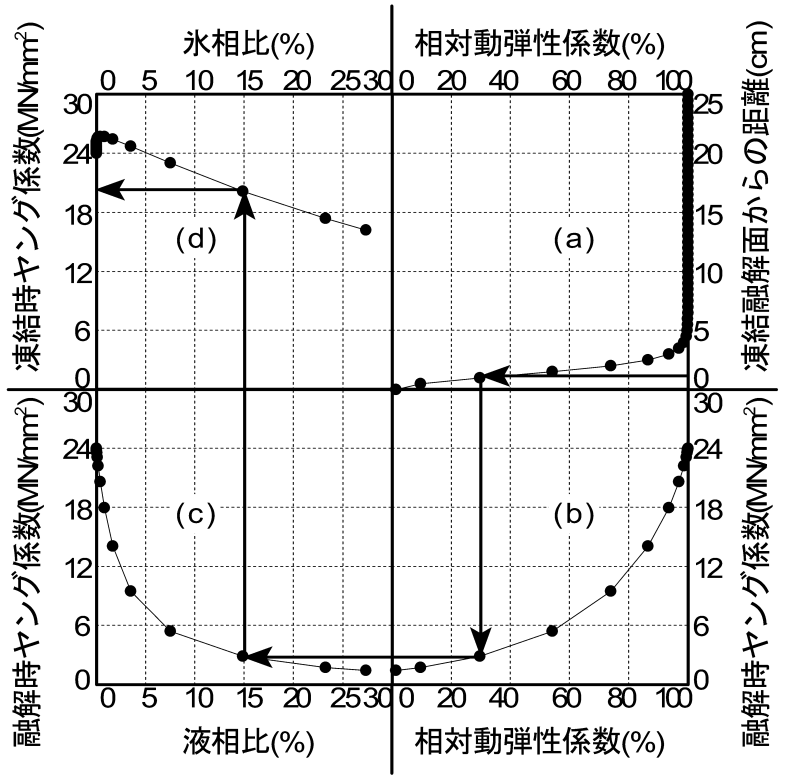

図-18 スラブ供試体内の凍結時におけるヤング 係数の算出方法（300 サイクル時）

$$
p=\frac{1}{1-\frac{1-\frac{E_{S}^{T}}{E_{0}}}{1-\frac{E_{S}^{T}}{E_{L I Q}}} \alpha}, \quad \alpha=\sqrt{\frac{E_{L I Q}}{E_{0}}}
$$

この脆弱相の比は 1 サイクルの凍結時と融解時で変 化しないと仮定し, 凍結時におけるコンクリートのヤン グ係数は, 図-17 (C) のように脆弱相が氷相に変化する と考えれば, 式(8)のように求められる.

$$
E_{S}^{F}=\frac{(\alpha-1) p+1}{\frac{\alpha \cdot p}{E_{I C E}}+\frac{1-p}{E_{0}}}, \quad \alpha=\sqrt{\frac{E_{I C E}}{E_{0}}}
$$

ここで, $E_{S}^{F}$ : 凍結時におけるヤング係数, $E_{I C E}$ : 水 相のヤング係数である.

また， $E_{0}$ は，劣化を伴わない基相のヤング係数であ り，凍結時においては最低温度に応じて変化する。低温 下にあるコンクリートは，温度が $0^{\circ} \mathrm{C} \sim-100^{\circ} \mathrm{C}$ 範囲で は，圧縮強度は温度低下とともに放物線的に増加するこ とが明らかとなっており，低温時の圧縮強度は式(9)の ように，また圧縮強度の増加量は式(10)のように求めら れる ${ }^{10)}$.

$$
\begin{gathered}
f_{c, T}^{\prime}=f_{c}^{\prime}+\Delta f_{c, T}^{\prime} \\
\Delta f_{c, T}^{\prime}=\left\{9.8-(T+180)^{2} / 3300\right\} \omega
\end{gathered}
$$

ここで, $f_{c, T}^{\prime}$ : 温度 $T$ における圧縮強度 $\left(\mathrm{N} / \mathrm{mm}^{2}\right)$, $f_{c}^{\prime}$ : 常温における圧縮強度 $\left(\mathrm{N} / \mathrm{mm}^{2}\right), \Delta f_{c, T}^{\prime}$ : 温度 $T$ に おける圧縮強度の増加量 $\left(\mathrm{N} / \mathrm{mm}^{2}\right), T$ : 温度 $\left({ }^{\circ} \mathrm{C}\right)$, であ る. $\omega$ : 含水量 $(\%, 28$ 日間水中養生の場合の平均で 7. 49\%)である.

さらに，低温下の圧縮強度とヤング係数との間には， 温度が- $10^{\circ} \mathrm{C} \sim-100^{\circ} \mathrm{C}$ 範囲では式(11)に示す関係が認 められている ${ }^{10)}$.

$$
E_{c, T}=0.3 f_{c, T}^{\prime}+13.7
$$

ここで， $E_{c, T}$ : 温度 $T$ におけるヤング係数 $\left(\mathrm{kN} / \mathrm{mm}^{2}\right)$ である。

したがって，式(8)から凍結時におけるヤング係数を 算出する際には, $E_{0}$ を $E_{c, T}$ に置き換え, 温度の影響を 考慮することとする.

次に, 融解時の脆弱相のヤング係数 $E_{L I Q}$ の算定方法 について述べる.

等方材料の場合，ヤング係数は次のように表される.

$$
E=3 K(1-2 v)=\frac{3}{\kappa}(1-2 v)
$$

ここで, $E$ : ヤング係数, $K$ : 体積弾性率, $v$ : ポ アソン比， $\kappa:$ 圧縮率である.

いま, 融解時の脆弱相では, 水が溶け水に変化して いるものと考え, 水の圧縮率 $0.45 / \mathrm{GPa}\left(20^{\circ} \mathrm{C}\right.$, 大気圧下 $)$ を用い, ポアソン比を 0.499 と仮定すれば，脆弱相の融 解時のヤング係数 $E_{L I Q}$ は, $13.3 \mathrm{MPa}$ となる.

最後に, 水相のヤング係数 $E_{I C E}$ の算定方法について 述べる. 水のヤング係数は温度の低下とともに大きくな ることが知られているが，ここでは Kong \& Campbe1111)の 解析報告をもとに次式を用いることとした.

$$
E_{I C E}=6.1(1-0.012 T)
$$

ここで, $E_{I C E}$ : 水のヤング係数 $(\mathrm{GPa}), T$ : 温度 $\left({ }^{\circ} \mathrm{C}\right)$ である。

いま，基相のヤング係数 $E_{0}$ を凍結融解作用を受ける 前のコンクリートのヤング係数 $24000 \mathrm{~N} / \mathrm{mm}^{2}$ と仮定して, 例えば，300サイクルにおける凍結融解面からの距離と 凍結時のヤング係数の関係を求めれば，図-18に示すよ うである。同図中 (a) は, 凍結面からの距離と相対動弾 性係数を示したものである. 凍結面から距離に応じた最 低温度変化よる深度方向の相対動弾性係数を推定するも のであり, 図-7および図-9から求められる。(b)は, 相 対動弾性係数と融解時のヤング係数の関係を示したもの である.（a）で求められた相対動弾性係数から融解時の 
ヤング係数を推定するものである，両者の関係は図-14 から求められる。ここで, 図-14に示した関係は, シリ ーズIの試験結果であり，シリーズIと配合および東結融 解試験の開始材齢が相違するが，その影響は少ないもの と仮定した. 図-14は，ある相対動弾性係数の際のヤン グ係数の比率を求めるものであり, 絶対值を直接的には 評価していないこと，水セメント比が相違した場合にお いても両者の関係はほぼ一つの曲線で表されること，粗 骨材最大寸法の差も比較的小さいことなどから，開始材 齢および配合が相違する影響は少ないものと仮定した.

(c) は，(b) で求められた融解時のヤング係数から液相比 を求めるものである. 両者の関係は, 式(7)から求めら れる. ここで, 液相比とは融解時の脆弱相の比である.

(d) は凍結時には液相が水相に変化するものとし，水相 比から凍結時のヤング係数を推定するものであり, 両者 の関係は式(8)から求められる.ここで，氷相比とは凍 結時には液相が氷相に変化すると考え，凍結時の脆弱相 の比である.

たとえば，図-18 から深度 $1 \mathrm{~cm}$ における凍結時のヤン グ係数を求めると次のとおりである. 相対動弾性係数は, 図-9 から求まる当該位置の最低温度に応じて図-7 から 29.7\%となる.このときの融解時のヤング係数は図-14 か ら $2860 \mathrm{~N} / \mathrm{mm}^{2}$ と算定される.このときの液相比は式(7) から $14.9 \%$ と算定され，凍結時には液相が氷相へ変化す るものとし，式(8)からこの箇所の凍結時のヤング係数 は, 20160N/ $\mathrm{mm}^{2}$ と算定される.

\section{d) 凍結による弾性ひずみ}

凍結融解作用を受けたコンクリート内に発生する力あ るいはひずみを求める方法としては，いくつかのものが 提案されている ${ }^{12,13), 14}$ が，本研究では凍結による弾性ひ ずみは，単純に次式で求められるものと仮定した.

$$
\varepsilon_{(y)}^{F}=\frac{V \cdot W_{f(y)} \cdot(1-\omega)}{3}
$$

ここで， $\varepsilon_{(v)}^{F}$ : 凍結によるひずみ, $V$ : 液相から水 相への体積変化, $W_{f(y)}$ : 凍結液相比, $\omega$ : 凍結圧の緩 和に関する係数（AE 剂の影響，非完全密閉の影響）で ある。

また, 凍結液相比 $W_{f(y)}$ は, 式(7) で求められる液相 比を用いることとした.

$$
W_{f(y)}=p_{(y)}
$$

凍結圧の緩和に倸わる係数 $\omega$ は, 本研究に用いたコ ンクリートがプレーンコンクリートであり，この場合の 緩和作用は少ないものと考え, 零とした.

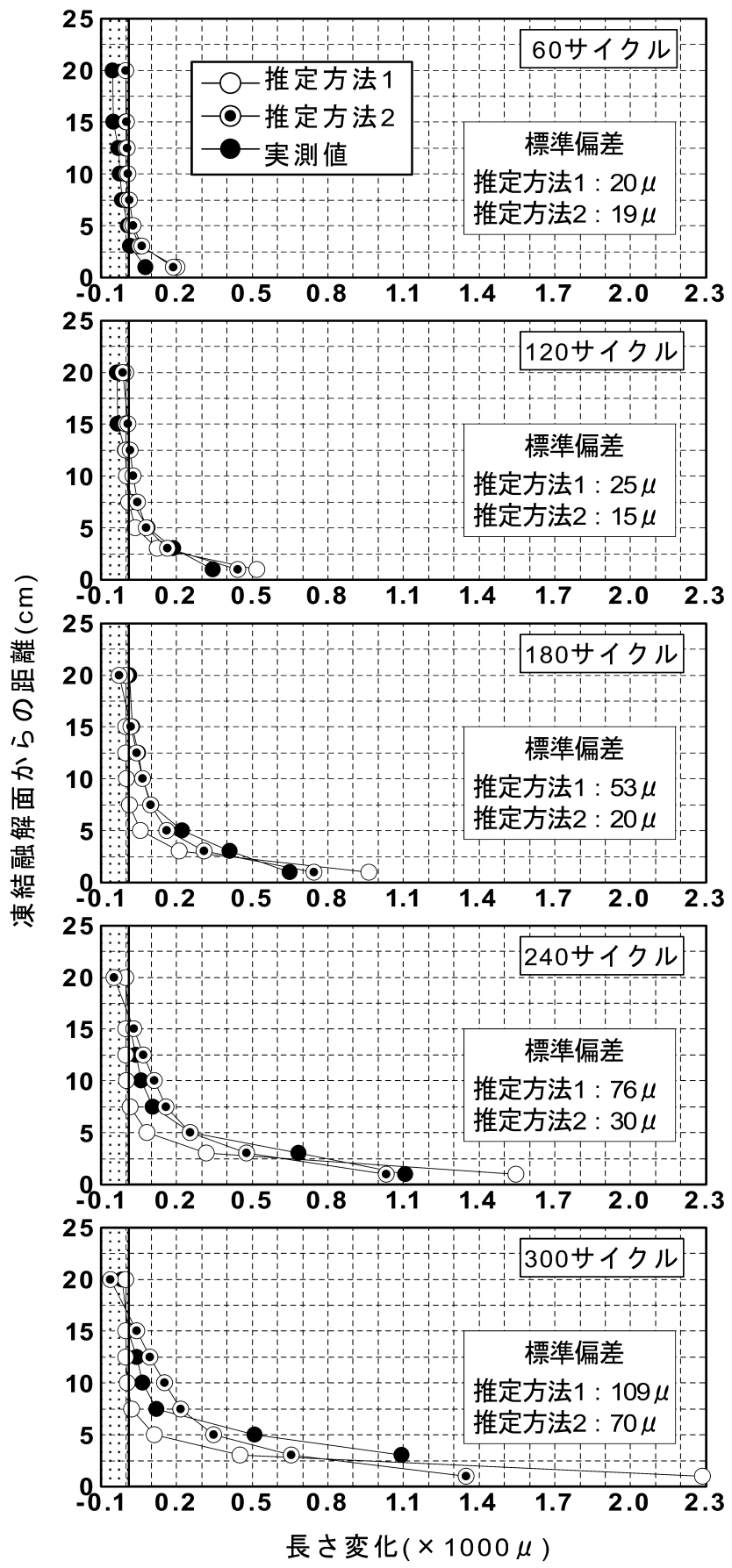

図-19 内部拘束力による残留ひずみを考慮した 長さ変化

\section{e) 内部拘束力による残留ひずみを考慮した長さ変化}

上述のような仮定を基に，内部拘束力による残留ひず みを考慮した長さ変化の推定結果を図-19 に示す．推定 に当たっては，式(3)における残留率 $(\varphi)$ を 0.3 と仮定 した.これによれば，劣化の相違による内部拘束力を考 慮した長さ変化（以下，推定方法 2 による長さ変化と呼 ぶ）は，当該位置の最低温度による長さ変化だけを考慮 した長さ変化（以下，推定方法 1 による長さ変化と呼 ぶ）と比較して，より実測に近づくことが認められる。 
すなわち，実測の長さ変化に対する各々の推定方法によ る長さ変化の差を標準偏差によって表せば, 図中に示し たとおりであり，各サイクルとも推定方法 2 を用いた場 合の方が，推定方法 1 を用いた場合と比較して, 標準偏 差が小さくなっており, 実測との差が小さくなっている ことが認められ, 特に表面から $1 \mathrm{~cm}$ 部分では推定方法 2を用いたことによる精度向上が比較的顕著である。ま た, 表面から $7.5 \mathrm{~cm}$ よりも深い部分では, 推定方法 1 に よる長さ変化は, 実測を小さく推定し劣化を過小に, 寸 なわち危険側に評価する傾向にあったが，推定方法 2 に よる長さ変化にはそのような傾向は認められない，ただ し, 表面から $3 \mathrm{~cm}$ 部分では未だ実測との差が大きいこ とも確認でき, 依然として推定值は劣化を過小に評価す る傾向が認められる. 本研究では, 通常の凍結融解試験 に用いられている供試体の温度を, 中心部の温度で代表 させており，断面内に生じうるであろう温度分布の影響 は少ないとの判断で検討を実施している. 寸なわち, 通 常の凍結融解試験に用いられている供試体には, 断面内 の温度分布に起因寸る内部拘束力の影響は少ないものと 仮定している. 実測值と推定值に未だ差がある原因とし ては，このような仮定を設けていることが影響している とも考えられ，今後検討を要するものと思われる.さら に, 300 サイクルでは推定方法 2 を用いた場合でも依然 として実測值との乘離が認められる.これは，270 サイ クル以降 $1 \mathrm{~cm}$ までの箇所に実験では部分的に断面欠損 が認められたが，推定に当たってはその影響が考慮され ていないことが影響しているものと考えられる.

以上のように，一面凍結融解作用を受けたコンクリ 一トの耐久性を, 同一最低温度下で全面から凍結融解作 用を受ける角柱供試体の結果を用いて推定しようとした 場合, 凍結表面では劣化を過大に, 内部では劣化を過小 に評価する. 本研究では, その原因の一つのとして，一 面凍結融解作用を受けた場合, 深度方向に劣化の程度が 相違することにより内部拘束的な力が働く影響の可能性 について解析的に検討を行った，その結果，凍結融解作 用を受けて弛緩した組織が凍結時には氷で両たされ, 弾 性的に挙動すると仮定すれば, 深度方向に自己平衡力が 働き, 非劣化部が劣化部の変形を拘束するように挙動す ることを示すことができた。 ただし，これはあくまでも 解析的な考察であり, 実験的に検証するまでには至って いない．今後この点について検討することが必要であり， また今回の検討対象が $\mathrm{AE}$ 剂を用いていないプレーンコ ンクリートであり， $\mathrm{AE}$ コンクリートにおいてもこのよ うな自己平衡力が働くか否かについても併せて研究して いく必要があるものと考えられる.

\section{6. 結論}

本研究は, 従来の促進凍結融解試験に替え, より実 構造物の露出状況に近い, 一面からの夕促進凍結融解作 用を受けるコンクリートの劣化を実験的に検討し，その 劣化を評価するに当たり従来の全面から凍結融解作用を 受けたコンクリートの劣化特性との相違を検討し，これ を実構造物に適用寸る場合の問題点の解明を試みた。

試験対象がAE剂を用いていないプレーンコンクリー 卜を対象としており, 検討範囲が限られているので断定 的なことは言えないが，本研究の範囲内でつぎのことが 言える.

（1）最低温度が低いほど，相対動弾性係数の低下が大き く, 長さ変化が大きく劣化し易くなり, 従来得られ ている知見と一致する.

(2) 凍結融解サイクル数の増加に伴う相対動弾性係数お よび長さ変化は, 最低温度を介した適当な関数式を 選ぶことによって, 精度良く表現することが可能で ある。

(3) 相対動弾性係数の低下とともに力学性能比は低下寸 るが, その程度は力学性能で相違し, 圧縮強度の低 下は動弾性係数の低下より小さく, ヤング係数の低 下は動弾性係数の低下よりも大きく, ヤング係数の 低下の方が圧縮強度の低下と比較して大きいことが 認められる。

(4) 相対動弾性係数の低下と圧縮強度比あるいはヤング 係数比の低下は水セメント比によらず, ほぼ一つの 曲線で表すことが可能であることが認められる.

（5）現行の水中凍結水中融解による試験結果を用いて, 同位の最低温度下におけるコンクリート内部の劣化 を推定した場合, 表面部は過大に内部では過小に評 価する可能性が高い.

(6) コンクリート内部の劣化が推定值よりも大きくなる のは, 表面部の劣化を拘束しょうとする力の影響と 考えられ，実構造物の表面からの劣化が最低温度だ けでは推定できない場合があることに留意すべきで あり, 自己平衡力の影響を考慮する必要があると考 えられる。

謝辞 : 本研究を実施するに当たっては，小林正几法政大 学名誉教授からご墾篤なるご指導を賜りました。ここに 深く感謝致します.

\section{参考文献}

1) 例えば，國分正扸 : 各種AE郕の使用方法に関する研究，土 
木学会論文集，第23号，pp.1-19, 1955.2

2) 石井清, 江川顕一郎, 堤知明, 野口博章 : 凍結融解作用を受 けるコンクリートの劣化予測に関する研究，土木学会論文 集, No.564/V-35,pp.221-232, 1997.5

3) 鎌田英二, 田畑雅幸，千歩修，伊藤和博 : ALCの凍害機構と 評価のための試験方法について，セメント技術年報，Vol.36， pp.436-439, 1982.

4) 山下英俊，堺孝司，佐伯昇 : 超音波伝播速度を用いた凍害深 さの推定，コンクリート工学論文集，Vol.7, No.2, pp.179-186, 1996.7

5）田畑雅幸，洪悦郎，鎌田英治：コンクリートの而凍害性に 及ぼす環境要因の影響, セメント技術年報, Vol.37, pp.349$352,1983$.

6）鎌田英治，洪悦郎：而凍害性指標としての長さ変化の適用 性，セメント技術年報，Vol.25，pp.313-316，1971.

7）小林正几 : コンクリートの凍結融解試験方法に関する $2,3 の$ 考察，セメント技術年報，No.23，pp.261-263， 1969.

8）岩崎訓明：コンクリートの特性，共立出版, 1975.12
9）大嶺聖, 落合英俊 : 二種混合体の応力一ひずみ関係と混合 土の一次元圧縮特性への適用, 土木学会論文集, No.448 / III-19, pp.121-130, 1992.6

10) 土木学会, 2002年制定コンクリート標準示方書[構造性能照 査編]，参考資料II，低温の影響（コンクリート）, 2002.3

11) Kong, W. L. and Campbell, T. I. : Thermal pressure due to an ice cap in an elevated water tank, Can. J. Civ. Eng., Vol.14, pp.519-526, 1987.

12) Powers, T. C. : A working hypothesis for further studies of frost resistance of concrete, J. ACI, Vol. 16, No.4, pp.245-272, 1945.2

13) 小原拓也, 小川憲治, 岩城一郎, 三浦尚 : 極低温まで泠却 されるコンクリートの劣化予測モデル構築に関する基礎的 研究，コンクリート工学論文集，Vol.14， No.2，pp.1-10, 2003.5

14) 三橋博三, 周志云, 多田眞作 : 微視的メカニズムを考慮し たコンクリートの凍結融解作用による变形挙動の数理モデ ル, コンクリート工学論文集, Vol.14, No.3, pp.33-44, 2003.9

(2005. 12.8 受付)

\title{
FUNDAMENTAL RESEARCH ON THE DETERIORATION DEPTH IN CONCRETE SUBJECTED TO FREEZE AND THAW
}

\author{
Hiroaki NOGUCHI, Yasurou MAKI, Toshiaki MIZOBUCHI and Keisuke YAMADA
}

In conventional accelerated tests all sides of specimen are exposed to Freeze and Thaw, whereas in actual concrete structures only one side would be exposed. This paper reports the experimental results by limiting the exposure to one side only, which is more similar to the actual condition. We took plain concrete without AE agent as an object of this study. In this paper, we reveal that 1) there is some discrepancy between the measured deterioration depth of one side test and the prediction results by conventional tests at the same lowest temperature; and 2) whereas the result of the conventional tests overestimates Freeze and Thaw durability in the inside, underestimates the durability of the surface on the tested side. This discrepancy is almost likely caused by the strain gradient along the specimen which induces a self-equilibrating set of forces. 